\title{
ガス架橋法による架橋ポリエチレン ケーブルの絶縁性能
}

\begin{tabular}{|c|c|c|c|}
\hline 立電線㧣式会社 & 水 & 上 & \\
\hline 日立電線株式会社 & 依 & 田 & 文 \\
\hline 日立電線㧣式会社 & 加 & 藤 & \\
\hline 日立電線校式会社 & & 田 & \\
\hline 立電線秼式会社 & & 橋 & \\
\hline
\end{tabular}

\section{1.まえがき}

架橋ポリエチレンケーブル（以後， CV ケーブルと 呼ふ）の高王化加最䜣急速に進的られている。古でに 66〜77kV 級にむいては実用化がなされて抽り，賁京

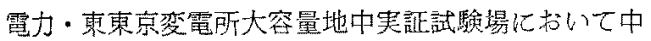

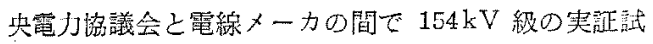

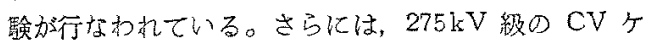
ーブルの開発が進められている。

ポリエチレン絶縁体は固体絶縁物中では誘電損失が 小さく，村料自身の絶縁酎力香非常に高い点から超高 電匤，超々高電圧ケーブルの絶縁体として適している と考えられる。しかしながら，堅際製造されたケー ブルの絶縁性能は材料自身の絶縁性能から期待される 水準よりb低い。超高電圧級 CVヶーブルの实用化を 望むためにはケーブルとしての絶縁酎力を高め，長期 信頼性至向上するとと本に絶縁娄低減加必要である。

現在末でに，絶緣性能の向上在目的として充てん 剂，ポリエチレンコンパウンドなどの材料配合面での 檢討，押出技術の改良，特に三檿同時押出法の探用な どが行なわれ，大きな成果が得られてきた。さらに， ポリエチレン總緣体中の铰視的欠陷の解消价着目して

Insulation Properties of Cross-Linked Polyethylene Cables Cured in Inert Gas. By T. MIZUKAMI, Member, B. YODA, Member, N. KATO. Member, C. IKEDA, Member \& K. TA-

KAHASHT, Member (Hitachi Cable Ltd.).

水上德五郎：正夏，日立管線株式会社

依田文吉：正員，日立篦橾株式会社

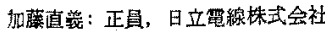

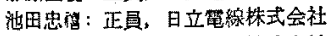

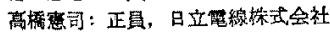

$\mathrm{SF}_{6}$ ガス走緦縁体中に应散浸透させ，絶縁耐力の问上

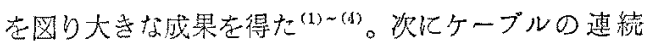

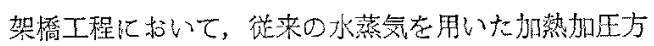
式によると亦分がポリチレン中に浸透し，兆学顕微

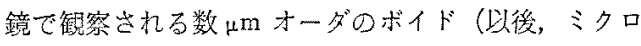
ボイドと呼ぶ）在形成することにも注慧が向けられ， 水蒸気等用いない架橑法が取り上げられだ。これるの

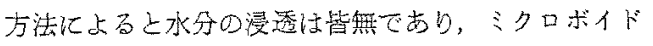
が観察されないととが敖台されている(5)(6)。

筆者らは高温高王力口不活性ガス $\left(\mathrm{N}_{2}, \mathrm{SF}_{6}\right)$ 気流中

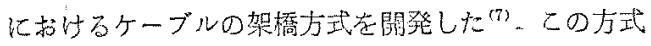
により作荿したケーブルの物理，化学的性質，電览特 性を詳細に検討した結夥，ポリエチレンの密度が高ま り，徒来残存していた水分，ミクロボイドは推察され ず，電気緦縁性能が蓄しく向上することがわかった。

\section{2. 高温高圧力の不活性ガス気流中における} ポリエチレンケーブルの加熱架橋方式

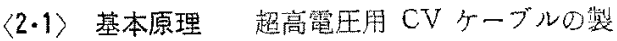
造にあたっては導体上に内部些尊電䲩，ポリエチレン

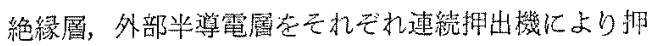
出する。押出されたコンパウンド中に混練されている 化学架橋剂 (通常, ディタミルパーオキサイド：DCP

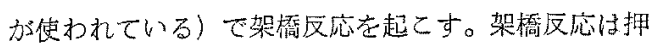
出機から下方に向加って金直あるいはカテナリ一状に 伸びている架橋筒内をケーブルが連続的に通過する際 に行なわれ，そこではケーブル架架橋反心に必要な温 度まで加熱すると同時に，架橋反応の分解生成ガスな 
どによる発泡を防ぐため適当な珐力で加纴している。 この架橋筒内におけるケーブルの加熱加生方式には広 く水蒸気が用いられており，高温老得るために約 13 $\mathrm{kg} / \mathrm{cm}^{2}$ 以上の压力に保たれている。

水蒸気の持つ利点は，ケーブル表面て㠜縮伝熱を行

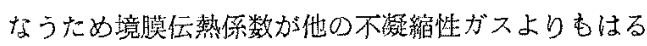
加にきく，ケーブルの加熱を容易に行なえることで

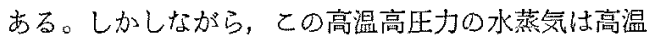
浴融状態にあるポリエチレン中に払散浸透し，ケーブ ルの冷却後ポリエチレン中で紑縮してミクロボイドを 班成する原因となり，さらに䉓舞絶縁特性をも大幅に 低下させるととがわかってきた。筆者らは，これらの 難点を除去するために高温高王力の不活性ガスでケー ブルを扣熱加Eする方法を試みた。不活性ガスの自然 刘流に上る境膜熱佉達倸数は㠜縮性の水蒸带に上比心著 しく小さいので，高温高圧力のガスの流机を作り境膜

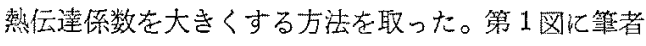
らの高温高压力ガス強制対流によるポリエチレンケー ブルの架橋方式の概念图を示す。

$\langle 2 \cdot 2\rangle$ 熱伝達特性 架橋筒之ケーブルとで形成 される同心円筒空間を离温高生力のガスが流れる際に 内部円笥であるケーブル表面における好流熱伝详㐿数 は(1)式で与えられる(8)。乙の場合，外筒加らの熱放 射は考えに入机ていない。

$$
\frac{h}{C_{p b} G_{b}}\left(\frac{C_{p b} \mu_{b}}{k_{b}}\right)^{2 / 3}\left(\frac{\mu_{w}}{\mu_{b}}\right)^{0.14}=\frac{0.023}{\left\{\left(D_{2}-D_{1}\right) \frac{G_{b}}{\mu_{b}}\right\}^{0.2}}
$$

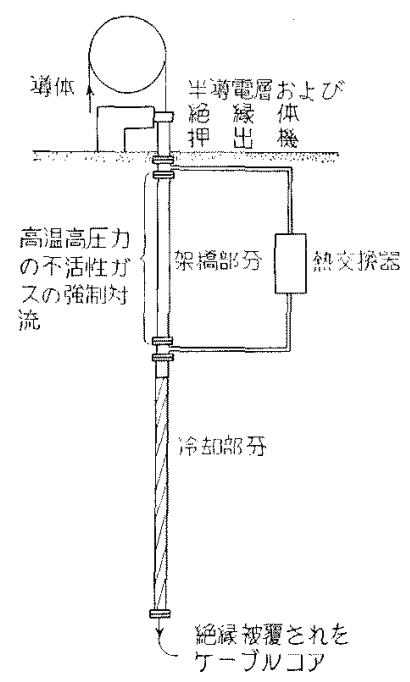

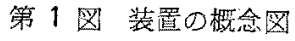

Fig. 1. Gas cure process.
ただし， $h$ : 熱伝達係数 $\left(\mathrm{cal} / \mathrm{cm}^{2} \cdot \mathrm{s} \cdot{ }^{\circ} \mathrm{C}\right), C_{p}$ ： ガスの定王比熱 $(\mathrm{cal} / \rho \mathrm{C} \cdot \mathrm{g}), k$ ：ガスの熱伀尊 度 $\left(\mathrm{cal} / \mathrm{cm} \cdot \mathrm{s} \cdot{ }^{\circ} \mathrm{C}\right), \mu: カ ゙ ス の$ 粘度 $(\mathrm{g} / \mathrm{s} \cdot \mathrm{cm})$,

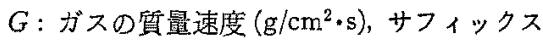
b: ガスの温度における物性䛧，サフィック ス $w$ : 管壁の温度に枋方物性值, $D_{2}$ : 外 部同心円筒内经 $(\mathrm{cm}), D_{1}$ ：内部同心丁筒外 径 $(\mathrm{cm})$

ケーブル絶縁体の加熱を考える場合には，ケーブル 表面に柎る境膜熱抵抗とケーブル表面加ら絶縁体最 网尿までのポリエチレン中の熱抵抗の雨者を考える必 要があり，それぞれの熱抵抗は次式で与えられる。

ケーブル表面における境膜熱抵抗

$$
R_{s}=1 / \pi D_{1} h
$$

ケーブル絶緣体の熱抵杭

$R_{c}=\left(1 / 2 \pi k_{0}\right) \log \left(D_{1} / D_{0}\right)$

ただし， $D_{1}$ : 絶䋑体外经 $(\mathrm{cm}), D_{0}$ : 絶縁体

内经 $(\mathrm{cm}), k_{0}$ : ポリエチレンの熱伝導度

$\left(\simeq 0.7 \times 10^{-3} \mathrm{cal} / \mathrm{cm} \cdot \mathrm{s} \cdot{ }^{\circ} \mathrm{C}\right)$

（1）式からわかるとおり，憼伝澾係数は流速放よび ガスの比董のそれぞれ0.8乘に比例して增加するこく から，気体の密度が大きく，流速が速いほど熱伝達保 数は大きくなり，境膜熱抵抗は小さくなる(第2园)。 次に，(2)，(3)式加ら $\mathrm{N}_{2}$ ガスの場合の $R_{c}, R_{s}$ O 関係を図示すると第 3 図になる。ケーブルを加熱する 場合には耐者の和が重要となる。徉来の蒸気架槅方式 の場合に杜，境膜熱任達係数は $0.14 \sim 0.68 \mathrm{cal} / \mathrm{cm}^{2}$. $\mathrm{s} \cdot{ }^{\circ} \mathrm{C}$ と非常に大きいととから，境膜熱抵抗 $R$ s はか゚ リエチレンの熱㨉抗 $R$ ～に比べて非常に小さく，全熱 抵抗はポりエチレン絶縁体の熱抵抗 $R$ 。にほば等し い。一方ガス架橋方式の場合にはケーブルの絶緣厚が 薄いほど境膜熱抵抗 $R$ ，は大きく，企熱抵抗は蒸気架 橋の埸合よりあかなり大きい。絶緣愿が厚くなってく

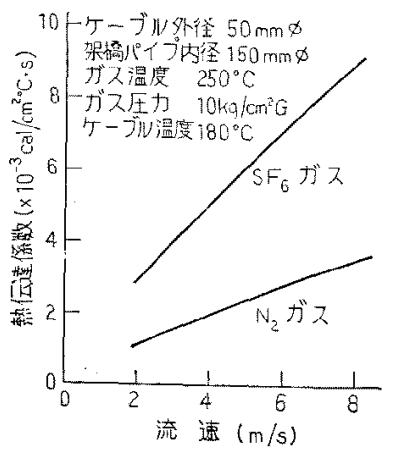

第 2 闵 ガスの流速と熱伝達係数の関係

Fig. 2. Coefficient of heat transfer in gas flow. 


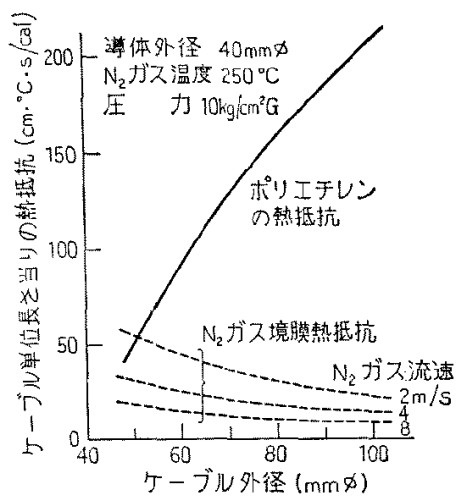

第了図 ケーブル表面に执ける境膜效抵抗 とケーブルの熱抵抗の絶縁厚依存性

Fig. 3. Dependence of heat resistance on insulation thickness.

ると境膜熱抵抗 $R s$ はポリエチレンの熱抵抗 $R_{c}$ 亿比 ベて小さくなり，全熱抵抗は主としてポリエチレン䋓 縁体の熱抵抗 $R_{c}$ に支配されるようになる。このよう に使用するガスの比重を考元，ガスの流速を適当に選 ふ心ことによって，ガス架橋方式を效率よく行なうこと ができる。

\section{3. 物理, 化学特性}

高温高圧力の $\mathrm{N}_{2}$ ガス気流中で架橋した CV ケーブ ル(以後， $\mathrm{N}_{2}$ ガス架橋 $\mathrm{CV}$ ケーブル上呼ぶ）の物理， 化学的な性質を従来方式の蒸気中で架橋したCVヶー ブル（以後，蒸気架橋 CV ケーブルと呼が）上対比し 検討する。

〈3.1〉物理的性質 闭 $\mathrm{CV}$ ケーブルの物理的 機械的性質を第 1 表化示す。引張試験，加熱变形は JIS-C-3606 に準じて行ない，動的粘弹性率 ${ }^{(9)}$ は直読 式動的粘弾性測定器に上り求め, 密度は密度勾配管 (ASTM-D-1505-68 亿準じる。测定精度小数点以下

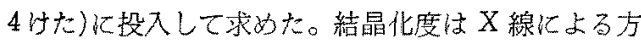
法 ${ }^{(20)}$ 加求めた。

引張強度, 加熱变形など機械的強度は両 $\mathrm{CV}$ ケーブ ルともに同程度の值を示している。また，動的粘弾性 率，結晶化度など们いてす差買は認められなかっ

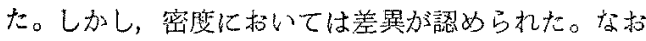
密度の算出方法は次のとおりである。同一ケーブル ロットに対して，た之えば絶縁厚 $6 \mathrm{~mm}(12 \mathrm{~mm})$ の場 合, 径方向仪 6 等分 (12 等分) し， 天0各層化対し 2 片の密度を測定し，その全部の平均値を算出する。表 中の範囲は口ットの邀いによる平均值のばらつきを示 している。CV ケーブルの泌度の低下の要因として，
符 1 表 ケーブルの物理特性

Table 1. Physical properties of CV cable.

\begin{tabular}{|c|c|c|c|c|}
\hline & 項 & 目 & 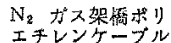 & 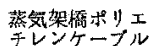 \\
\hline 引 & 常 & T.S $\left(\mathrm{kg} / \mathrm{cm}^{2}\right)$ & 2.23 & 2.25 \\
\hline 張 & 温 & T. E $(\%)$ & 477 & 470 \\
\hline 强 & 若 & T.S $\left(\mathrm{kg} / \mathrm{cm}^{2}\right)$ & 2.10 & 2. 17 \\
\hline 度 & 後 & T.E (\%) & 487 & 483 \\
\hline & 变开 & $\begin{array}{l}120^{\circ} \mathrm{C}, 30 \mathrm{~min} \\
W=6 \mathrm{~kg}(\%)\end{array}$ & 11.9 & 11.8 \\
\hline & 弹址 & $E^{\prime}\left(\mathrm{dyn} / \mathrm{Cm}^{2}\right)^{*}$ & $2.4 \times 10^{\circ}$ & $2.4 \times 10^{9}$ \\
\hline & 䭫失政 & $E^{\prime \prime}\left(\mathrm{d} y \mathrm{n} / \mathrm{cm}^{2}\right)^{*}$ & $2.9 \times 10^{8}$ & $2.9 \times 10^{8}$ \\
\hline & 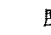 & $(g / c c)$ & $0.9185 \sim 0.9195$ & $0.9170 \sim 0.9180$ \\
\hline & 厚化 & & $64 \sim 68$ & $65 \sim 68$ \\
\hline
\end{tabular}

（1）ポリエチレンの架橋化および熱履㰮，(2)ケーブ ル中泟存する架憍分解生成物，水分，ミクロボイド なぼが考えられる。

〈3.2〉 ケーブル絶緑体内の架橋分解生成物およひ 水分の分布 CV ケーブル絶縁体中に残存する物質 は，架橋分解生践物就よで水分が主であると考えられ る。架橋分解生成物の大部分はアセトフェノンである からら ${ }^{(11)}$; 了女トフェ/ンの $C=O$ 基の赤外吸収スペク トルに着目し，その定量を行ない，両CVヶーブルに ついて層別にアセトフュノンの残存量を比較した（第 4 図)。これによると両 CV ケーブルの間には差が認 为ら机ず，元の分布絶縁体の内外退で小さく，中央 付近でピークを描いている。

水分量の測定にあたっては赤外分光器を用い，圆体 水分計で校正を行ない定最した。 $\mathrm{N}_{2}$ ガス架橋 $\mathrm{CV}$ ケ ーブルでは絶縁体全象にわたって $\mathrm{H}_{2} \mathrm{O}$ 特有の幅広い 赤外吸收スペクトルを検出するてとができなかったて とから，絶縁体中に水分が含まれていない上考无られ

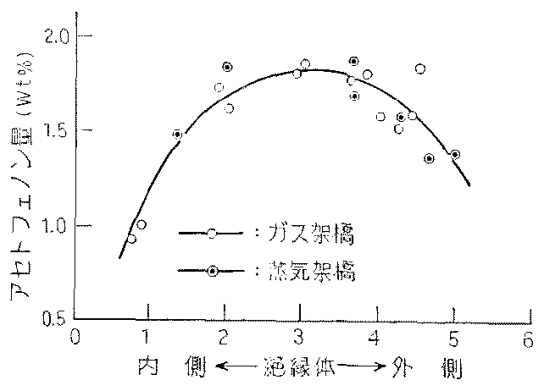

第 4 図 ケーブル内の架橋分散残査(アセ卜 フェノン）の分布

Fig. 4. Distribution of decomposition residue of cross linking agent (Acetophenone) in a CV cable. 


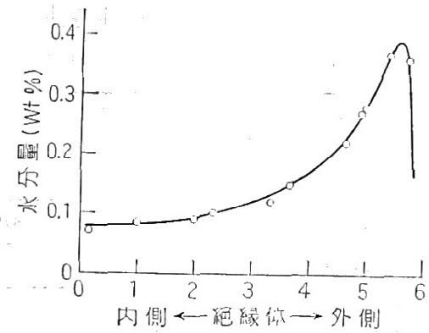

第 5 図蒸気架橋ポリエチレンケーブル内 の水分の分布

Fig. 5. Distribution of water in a CV cable. る。一方, 蒸気架橋 CV ケーブルでは第 5 図に示すよ うに絶縁体の全層にわたって水分が検出され，特に絶 縁体の外層部に多いととがわかった。

〈3.3〉 ケーブル絶緣体の顕微鏡観察 両 $\mathrm{CV}$ ケ ーブル絶縁体内部を光学顕微鏡およよび走査形電子顕微 鏡を用いて観察した。観察方法は次のとおりである。 光学顕微鏡を用いるときには，絶縁体をスパイラルカ ットした後, その薄片の内部它観察する。走査形電子 顕微鏡を用いるときには，絶縁体を液体空素中で十分 冷却した後, 絶縁体を径方向または長手方向に破断し, その表面に金蒸着を行ない，その表面を観察する。

第 6 図，第 7 図は乾燥処理前の両 CV ケーブルの外 層部（第 5 図中番号 5，6の間の位置）のミクロボイ ドの密集状態（光学顕微鏡による）と，内層部（第 5 図中番号 1，2 の間の位置）抢よび外層部の球晶構

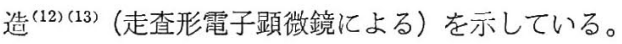

第 8 図は十分乾燥処理した蒸気架橋 CV ケーブルの 外層部の光学顕微鏡および走査形電子顕微鏡写真を示 す。ガス架橋 CV ケーブルの場合には乾燥処理前後で 変化が胃られなかった。これら顕微鏡観察結果と前項 とを合わせると次のととがわかる。

（1）ミクロボイドはガス架橋 CV ケーブルの場合 絶縁体全層にわたって観察されなかった。一方，蒸気 架橋 CV ケーブルの場合には径方向でミクロボイドの 密集状態が異なっており，その度合いは絶縁体中に残

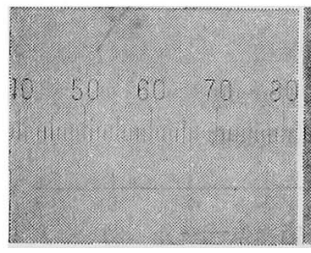

$\mathrm{N}_{2}$ ガス架橋 $\mathrm{CV、ケープル}$

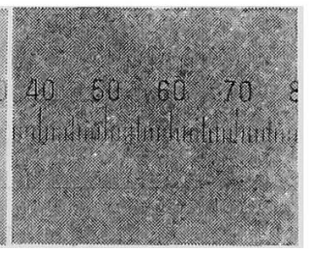

蒸気架橔 CV ケーブル
第 6 図 絶縁体中のミクロボイドの光学顕 微鏡観察（倍率 100）

Fig. 6. Optical micro-photograph of the micro-voids of CV cables. $(\times 100)$
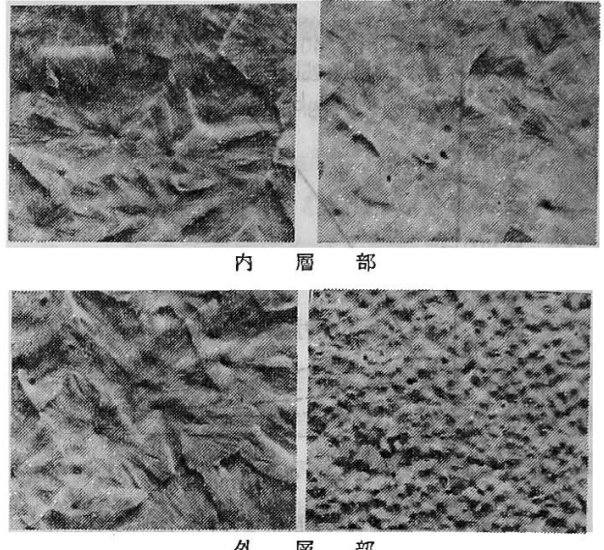

$\mathrm{N}_{2}$ ガス架橋 $\mathrm{CV}$ ケーブル蒸気架橋 $\mathrm{CV}$ ケーブル

第 7 図絶縁体の球晶の走査形電子顕微鏡 観察 (倍率 500)

Fig. 7. Electron scanning micro-photograph of the spherulites of CV cable. $(\times 500)$

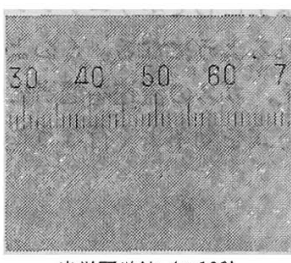

光学顕微鏡 $(\times 100)$

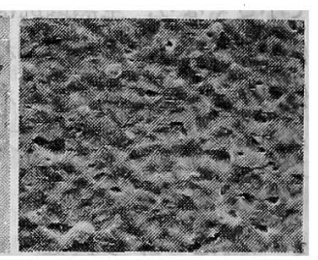

走査形電子顕微鏡 $(\times 500)^{\circ}$
第 8 図 乾燥処理後蒸気架橋 $\mathrm{CV}$ ケーブル の外層部

Fig. 8. Optical and electron scanning microphotograph of steam-cured $\mathrm{CV}$ cable after drying.

存する水分量の分布と対応している(14)(15)。さらに, こ のケーブルを高温で十分に乾燥処理するとミクロボイ ドの多くは光学湿微鏡で観察されなくなる。

（2）球晶構造はケーブルの径方向，長手方向とむ 同一北状をしており変化が兒られない。

（3）球晶構造については， ガス架橋 CV ケーブル では絶緑体全層にわたって同一形状のむのが観察され るが, 蒸気架橋 $\mathrm{CV}$ ケーブルでは絶縁体の内屬部と外 層部で大きな違いが見られる。この内層部の球晶構造 はガス架橋ケーブルの場合と類似している。一方，外 層部の球晶棈造は非常に細かいもの亡なり，形状も前 者と異なっている。さらに，このケーブルを高温で十 分に乾燥しても球晶の形状は変化しないで中心部(核) の様相が変化している。

（4）ミクロボイドと球鼠の密集度合いは水分量の 分布と対応しており, アセトフェノン量の分行とは関 係なさこうである。 
（5） ミクロボイドなどは球晶の核となっているよ うであり，ミクロボイドを生成るる主要因として，ヶ ーブル架橋時の苲気が考えられ，絶縁体中に漫透した 水蒸気がケーブルの冷相過程で水滴となり，ミクロボ イトを生成するすの上思われる(16)。

\section{4. 電気特性}

$\mathrm{N}_{2}$ ガス架橋 CV ケーブルの絶縁破壊特性と $\tan \delta$ 特

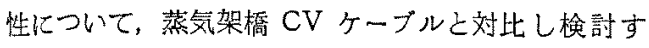
る。

〈4・1〉供試ケーブルおよひ課電方法彷来の蒸 気架橋 $\mathrm{CV}$ ケーブルの $22 \sim 154 \mathrm{kV}$ 級相当の絶縁厚 の $\mathrm{N}_{2}$ ガス架橋 $\mathrm{CV}$ ケーブルの絶縁性能を調べるため に次のケーブルを製造した。

$\begin{array}{lll}22 \mathrm{kV}-60,100 \mathrm{~mm}^{2} & \text { 絶縁写 } & 6 \mathrm{~mm} \\ 33 \mathrm{kV}-100 \mathrm{~mm}^{2} & \text { " } & 9 \mathrm{~mm}\end{array}$

$66 \mathrm{kV}-80,100,150,250 \mathrm{~mm}^{2}$ 絶縁厚 $\quad 11.5 \sim 15.5 \mathrm{~mm}$ $154 \mathrm{kV}-1,200 \mathrm{~mm}^{2} \quad$ " $20 \mathrm{~mm}$ 上記ケーブルの内外半導電層, 絶縁体の材質はそれ ぞれ同一のものを用い，特に絶線体には材料の影響を 避けるため, 無添加, 無充てんのものを用いた。ケー ブルへの課電方法は第 2 表に示すと抢りであり，破壊 に供する試料の多くはそれぞれ 4 亿 本である。

〈4.2〉インパルス破壊特性試験は常温で実施 した。供試ケーブルは両架橋 CV ケーブルともに，乾 燥处理前後のものである。インパルス破壊値の絶緣厚

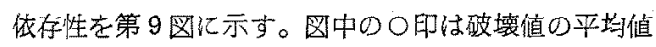
を示し，上限，下限をむ合わせて示す。

図から次項のととがわかる。

（1） $\mathrm{N}_{2}$ ガス架橋 $\mathrm{CV}$ ケーブルの破填平均電界強 度は 80 105kV/mm 以上であり，最高 $160 \mathrm{kV} / \mathrm{mm}$ に達するものもある。

（2）乾操処理前後の絶縁性能の比較を行なうと， ケーブルを十分乾懆するととによって， $\mathrm{N}_{2}$ ガス架橋 $\mathrm{CV}$ ケーブルの場合，性能は若干向上するが，その差

第 2 表 課電方法 (初期值)

Table 2. Method of voltage application.

\begin{tabular}{|c|c|c|}
\hline ヘープル & 艾流破揾試駼 & インパルス破技諴験 \\
\hline $22 \mathrm{kV}$ 級 & $200 \mathrm{kV} / 1 \mathrm{~h}$ & $\ominus 400 \mathrm{kV} / 3$ 回 \\
\hline $33 \mathrm{kV}$ 秋 & $300 \mathrm{kV} / 1 \mathrm{~h}$ & $\ominus 500 \mathrm{kV} / 3$ 回 \\
\hline $66 \mathrm{kV}$ 积 & $400 \mathrm{kV} / 1 \mathrm{~h}$ & $\ominus 700_{\mathrm{a}} \mathrm{kV} / 3$ 回 \\
\hline $154 \mathrm{kV}$ 数 & $500 \mathrm{kV} / 1 \mathrm{~h}$ & $\Theta 900 \mathrm{kV} / 3$ 回 \\
\hline
\end{tabular}

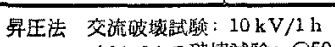
インパルス破枝践弱: $\ominus 50 \mathrm{kV} / 3$ 回

Vol. 94-A, No. 7

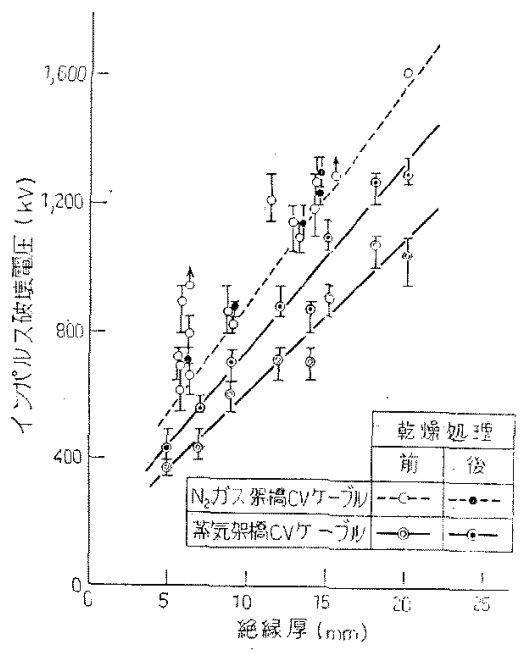

第 9 図 1ンパルス破罗特性

Fig. 9. Dependence of impulse breakdown strength on insulation thickness.

はわずかである。一方，蒸気架檔 $\mathrm{CV}$ ケーブルの場台 には﨡能は約 15〜35\% 问上し，ケーブルの乾燥処理 ○效榡が大きい。

（3）蒸気架楆 CVケーブルの破燷值 (平均値)之 比較すると， $\mathrm{N}_{2}$ ガス架橋 $\mathrm{CV}$ ケーブルのそれは乾噪

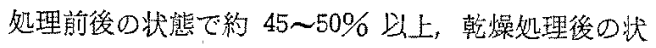
態で 20 25\% 以上向上している。

〈4.3〉交流破壊特性試験は常温で实施した。

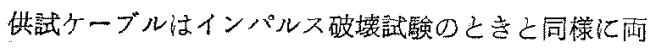

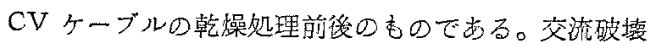
値の絶縁厚供存性在第 10 困に示す。罒中の記号は第 9 図之同じである。図から次項のことがわかる。

(1) $\mathrm{N}_{2}$ ガス架橋 CV ケーブルの破羁平均電界强 度は $40 \sim 55 \mathrm{kV} / \mathrm{mm}$ である。

（2）乾焺処理前後の絶縁性能の比較を行なう之, ケーブルを乾燥するととによってガス架橋 CVケーブ ルの場合は若干低下しているが，その差はかずかであ る。しかし，蒸気架橋 CV ケーブルの場合には妁 20

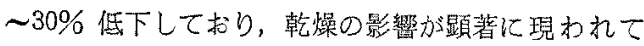
ける。

（3）蒸気架楆 CVケーブルの破填值(平均值) と比 較すると， $\mathrm{N}_{2}$ ガス架虂 $\mathrm{CV}$ ケーブルのをれは㲦燥姏 理前の状態で約 30 50\%向上し，乾燥処理㖟で 60 100\%向上している。

〈4.3〉 $\tan \delta$ 特性 $66 \mathrm{kV}$ 級の两 CV ケーブル の $\tan \delta$ 比較する上第 3 表の上うになる。 $\mathrm{N}_{2}$ ガス 架橋 CVケーブルの $\tan \delta$ はさく，ケーブル中の

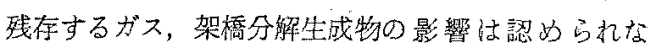




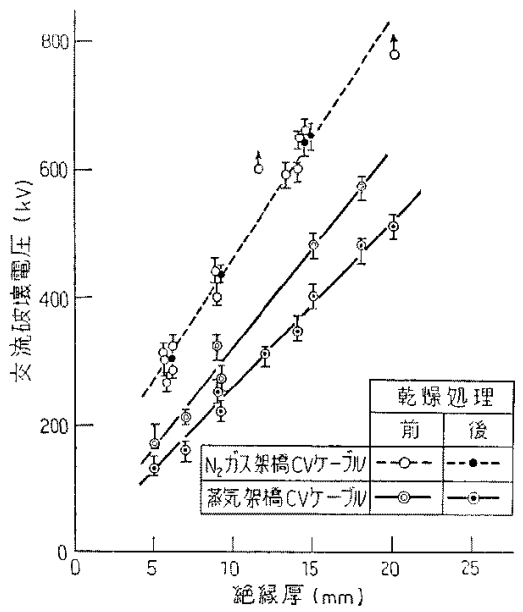

第 10 图 交流破境特性

Fig, 10. Dependence of AC breakdown strength on insulation thickness.

籍 3 表 $\tan \delta$ 特性

Table 3. Dielectric loss.

\begin{tabular}{|c|c|c|}
\hline ケーブル & $38 \mathrm{kV}$ & $76 \mathrm{kV}$ \\
\hline $\mathrm{N}_{2}$ ガス架沀ボリエチレンケーブル & $0.009(\%)$ & $0.009(\%)$ \\
\hline 蒸気如橋ポリエチレンケーブル & 0.015 & 0.017 \\
\hline
\end{tabular}

い。一方，蒸舜架橋 CVゲーブルでは残存する水分の 影響のためtandは大さくなっている。

\section{5. $\mathrm{SF}_{6}$ ガス架橋 $\mathrm{CV}$ ケーブルの電気䋓縁性 能}

絶縁耐力が $\mathrm{N}_{2}$ ガスの約 2 倍強である $\mathrm{SF}_{6}$ ガスを用

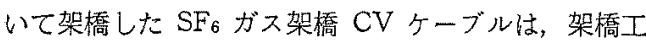
程中に $\mathrm{SF}_{6}$ ガスが䋓緑体中に拡散漫透するた的に，さ らに絶縁性能が向上すると思われる。こてで， $22 \mathrm{kV}$ $100 \mathrm{~mm}^{2}$ Ф $\mathrm{SF}_{6}$ ガス架橋 $\mathrm{CV}$ ケーブルを裴造し検討 した(第4 表)。表から次項のことがわかる。

（1）インパルス破塄值は $\mathrm{N}_{2}$ ガス架橋 $\mathrm{CV}$ ケーブ ルのそれと同程度でありガスの種類の影響は認めら れない。

（2）交流破罗值は $\mathrm{N}_{2}$ ガス架橋 $\mathrm{CV}$ ケーブルのそ れよりも高く約 $25 \%$ 向上している。

\section{6. 絶縁性能に及ぼす要因}

第 9 図，第 10 图に示すと抢り， $\mathrm{N}_{2}$ ガス架僑 $\mathrm{CV}$ ケ ーブルは蒸気架橋 CVケーブルと比較して大幅汇絶縁 性能が向上している。CV ケーブルの絶縁性能に特に 大きく影響する要因として，大別して次項のととが考
第 4 表 $\mathrm{SF}_{6}$ ガス架橋 $\mathrm{CV}$ ケーブルの絶縁 性能 $\left(22 \mathrm{kV}-100 \mathrm{~mm}^{2}\right)$

Table 4. Insulation properties of $\mathrm{SF}_{6}$ gascured $\mathrm{CV}$ cables. $\left(22 \mathrm{kV}-100 \mathrm{~mm}^{2}\right)$

\begin{tabular}{|c|c|c|}
\hline & 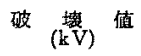 & $\begin{array}{c}\text { 破填平均電界強度 } \\
(\mathrm{kVm}\end{array}$ \\
\hline 交 & 408 & 68 \\
\hline インパルス & 728 & 121.3 \\
\hline
\end{tabular}

えられる。

（i）電極と絶縁体界面の接着㧍よで凹凸

（ii）絶緑体材料汇混入した異物

（iii）絶緑体中江残存する水分，架橋分解生成物

（iv）緦縁体の微視的構造(ミクロボイドなど)

本諭文で問題にしている架橋方式は要因（iii)，(iv） に主眼が置かれたものである。要因(而)の絶縁体中の 水分あるいは架橋分解生成物は，乾燥処理を行なうこ とによってケーブル中から大部分取り除ける。そこで まず始めに（iv)の要因について考察する。

\section{〈6.1〉 ポリエチレン絶縁体の微視的構造亡絶緑性}

能第 9 図，第 10 図で乾懆処理を十分行なった後 の両 CV ケーブルを此校すると， インパルスで 20〜 $25 \%$ 以上，交流で $60 \sim 100 \%$ 程度ガス架橋 $\mathrm{CV}$ ケー ブルの破罗值が高い。こ机山絶縁体の微視的構造の差 によるものと思われる。第 8 図行示すとおり，蒸気架 橋 CV ケーブルに観察されるミクロボイドは乾燥処理 を行なうと光学顕微鏡ではほとんで観察されなくなる が，球晶構造にはほとんど変化が見られず，空げきは 残っているようである。この残存するミクロボイドは どの欠陌部と，さらには第 2 表に示す密度の差が絶縁 性能汇影響しているものと考えられる。てれらの影響 について，おのおのの事例で考察する。

（1）ミクロボイドの影響ミクロボイドの影響 を直接的に㛟討するととはむずかしいため，筆者らは $\mathrm{SF}_{6}$ ガスを絶縁体中に拡散浸透させる方法で愉討し た。

蒸気架橋 CV ケーブルの場合には，ケーブルを十分 乾燥した後， $\mathrm{SF}_{6}$ ガスを絶縁体中に拡散漫透させる。 ガス架橋 $\mathrm{CV}$ ケーブルの場合には，架橋工程中に $\mathrm{SF}_{6}$ ガスを絶縁体中に昖散漫透させる方法をとった。

絶緑体中に $\mathrm{SF}_{6}$ ガスが含まれているが゙うが，前 者は重量変化扰よび赤外吸収スペクトルで，後者は赤 外吸收スペクトルで確認し，絶緑体全層にわたって $\mathrm{SF}_{6}$ ガスが含まれていることを磼認した。これらケー ブルの絶縁性能を第 11 図に示す。供試ケーブルは次 のとおりである。(a) 乾燥処理した $11 \mathrm{kV}-150 \mathrm{~mm}^{2}$ 


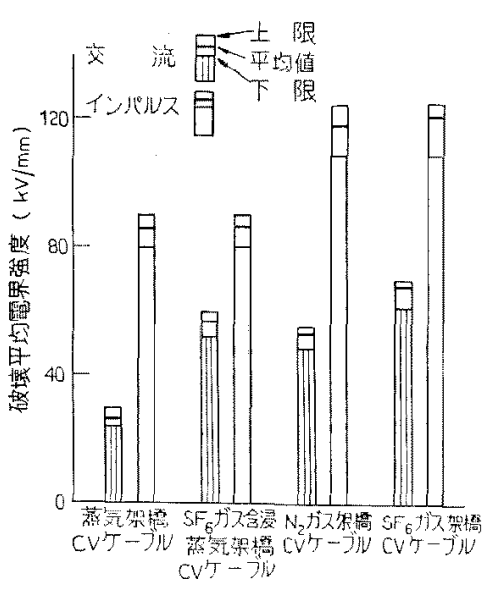

第 11 図 $\mathrm{SE}_{6}$ ガスの効果

Fig. 11. Effect of $\mathrm{SF}_{6}$ gas.

蒸気架橋 $\mathrm{CV}$ ケーブル(絶縁厚 $5 \mathrm{~mm})^{(17)} ，(\mathrm{~b})(\mathrm{a}) の$ ケーブルに SF 6 ガス在含漫させた $\mathrm{SF}_{6}$ ガス含浸蒸気 架橋 CV ケーブル，(c) $\mathrm{N}_{2}$ ガス架橋 $\mathrm{CV}$ ケーブル

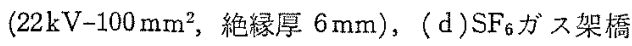
$\mathrm{CV}$ ケーブル $\left(22 \mathrm{kV}-100 \mathrm{~mm}^{2}\right.$, 絶縁厚 $\left.6 \mathrm{~mm}\right) 。(\mathrm{c})$, (d) は乾燥処理前のあのである。

各種ケーブルの絶縁性能を比较すると，次の順にな る。

交流破填强度 $(\mathrm{d})>(\mathrm{b}) \simeq(\mathrm{c}) \gg(\mathrm{a})$

インパルス破壊強度 $(\mathrm{d}) \simeq(\mathrm{c})>(\mathrm{b}) \simeq(\mathrm{a})$

とのことから，前述したように蒸気架橋 $\mathrm{CV}$ ケーブ ルではミクロボイドなどの久陮部があり，材料の絶縁 性能に比してケーブルではまだ十分な性能を発摷し得 ないものと思われる。また，ガス架橋CVヶーブルに 扣て古 $\mathrm{SF}_{6}$ ガス中で架楅したケーブルのほうが $\mathrm{N}_{2}$ ガス架橋ケーブルよりる交流の絶縁性能力腺いととか

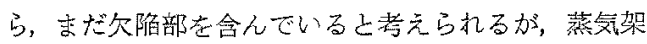
橋CV ケーブルを比較すると大幅に久楩部は改善され ていると考えられる。

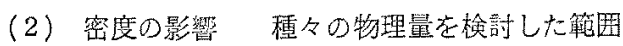
では密度のみが暴なっている。そしで，ケーブルと同 一材筫のポリエチレンを用いて密度の異なるシートサ ンプルを作成し，インパルス破填強度在調へると第

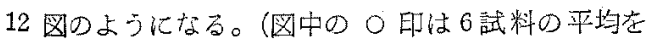

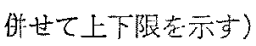

サンプルの作成方法杜次のとおりである。試料立一 定条件下でプレス架橋した後，熱好理を行学って密度 を変化させる。熱起理は次の3と持りである。

$140^{\circ} \mathrm{C}$ で 30 分間保持した後，(a)水水中に投入，

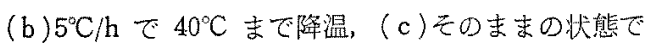

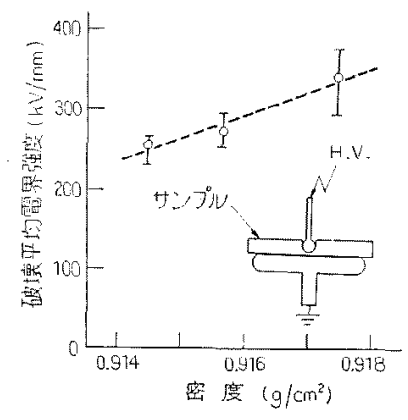

第 12 图 架橋ポリエチレンの密度上 インパルス破罣強度の関係

Fig. 12. Dependence of impulse breakdown voltage on density of cross-linked polyethylene.

冷却。

冷却時閒を比較すると，(a)，(b)，（c)の䫏に長 くなっていて，密度も順次大きくなっている。

グラフから密度の大きいほうがインパルス破塄強度 も高くなっているととがわかる。

密度已結晶化度の間に犆螕関係 ${ }^{(18)}$ 加市るが, X線 による結晶化度の求め力は精度がたりず，策者らの密

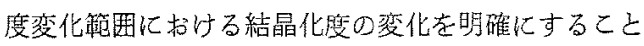
ができない(第 2 表参照)。一般に高密噔乞低密度ポリ エチレンの比較がされているが，製造方法の薏い， 实験者の違いなどにより比較しにくい(19)。同一材質を 用いて種々の結晶化度を特った試料を作成して，結晶

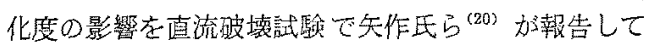
いるが，常温付近の破壊强度の傾向は課電波形の違い があるが，篗者らの傾向と買なっている。

以上の怙のかのの考察加ら、ミクロボイドなどの絶 緑体棈造上の欠樎部分は主として交流破壤強度と密唼 な関係があり，密度と関逨した絶蠓体の組織はインパ

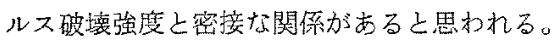

〈6.2〉絶線体中に残存する水分および架橋分解生 成物(主成分アセトフェノン)の影響

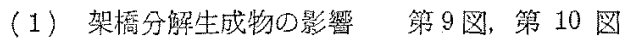
からわかると如りガス架橋 CVケーブルの場合，乾燥 処理前㣪で維縁性能には看息差が㒛められない。この

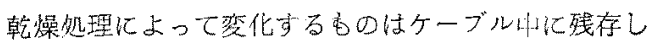
ている架橝分解生成物（主としてアセ卜フェノソ）て ある。このととから，アセトフェノンはガス架撟 CV ケーブルの破㙘強度に影響していないと考えられる。

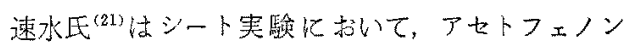
の効果を詳縕に検討して下記の結果を得ている。アセ

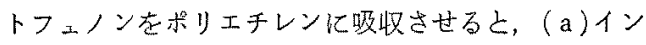
パルス破堎强度は变化しないか，交流では阿上し，莤 
流では低下する。（b )交流隹対するそれの勃果は主之 して霓極上絶縁体界面にあり，そこでの放䉓を抑制し 絶縁体内でのその効果は少ない。また（c)一般に針 電極加らの交流卜リ一開始電正はアセトフェノンによ り大きく上昇吉るととが知られている。

上記三つの挛実を総合する上下記の考察が可能であ る。アセトフェノンは電極と絶縁体との界面あるいは 絶縁体中のミクロボイドなど構造上の久陷部分で微小 な放電加生ずるような場合には放電抑制効果に上り交 流破壊強度向上させる。しかしながら，内部外部半 導電層之絶縁体を同時に押出し，加つ，ミクロボイド

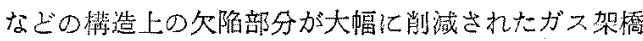
CV ケーブルに沾いては，その上うな微小な放電を生 ずる部分が少ないため，インパルス，交疏ともにアセ トフェノンの効果住期待できない。

（2）水分の影響 第 9 图，第 10 図少らわかる とおり，筣気架橋 CVケーブルでは乾燥処理によって インパルス破填强度は約 15 35\% 上昇し，交流破罗 強度は約 20〜30\% 低下する。この乾燥処理によって 水分上架橋分解生成物の両方が絶縁体上り飛散してお り，その両者の影響を考えなければならないが，前節 の所論からアセトフェノンのインパルス破壊強度の影 響は少ないと考兊られるので，蒸気架橋 CV ケーブル のインパルス破㯰強度が乾燥に上り上昇するのは絶縁 体中の水分がなくなるためであるうと考えられる。一 方，交流破壊強度の低下はミクロボイドなどの構造上 の欠険部から，アセトフェノンが飛散するととが大き く影響していると思和れ，水分がてれにどう作用して いるかは説明できない。しかし，他の研究者によって 絶縁体中の水分の影響について議論されている。た之 えば，シートサンプルを用いて，矢作氏ら ${ }^{(22)}$ は直流 で，会田氏ら ${ }^{(23)}$ 恔交流で検討し，水分を含んでいるポ リエチレンでは前者の場合約 20\%，後者の場合約 30 \%とも低下する。岩田氏ら (24) はケーブルを用いて 众討し，交流で約 30\%，インパルスで若干低下する ことを報告している。

以上を総合すると，ケーブル絶縁体中に水分がない のみならず，棒造的にはミクロボイドがなく，密度が 大きいためにガス架橋 CV ケーブルの絶緑性能は蒸気 架橋 CVケーブルよりあすぐれていると考えられる。

\section{7. むすび}

これまで述べてきたととを要約すると，

（1）適当なガス，流速を選ぶことにより，高温高 任のガス気流中でケーブルを架憍することが可能であ る。
（2）蒸気架橋 CVケーブルが十分な絶縁性能を発 撣できな加った主要因は，ケーブル製造時に絶縁体中 に浸透する水分と，乙れによって形成されるミクロボ イドが残存しているためと思机机る。

（3）緦縁性能を乾燥した状態で蒸気架橋 CVケー ブルと比較すると，交流で約 60〜100\%，インパルス で約 20〜25\% 以上， $\mathrm{N}_{2}$ ガス架梧 $\mathrm{CV}$ ケーブルは向 上しているので絶縁厚の低減が可能之思われる。

(4) 高電界における長期安定性について検討中で 古り，他の要因について季検討すべき点は多々存在し ているが，初期性能加ら見るかきり，CVケーブルの 超々高王化一の啇芯忛分可能で尚ろうと考えられ る。さらに，ガス架橋 CVケーブルを密閉パイプ中で $\mathrm{SF}_{6}$ ガスを加在した状態で用いることは，水分拉よさ 浸食性化学物得の絶縁体への浸透を防止主るととも に，光学顕徽鏡で観察し得ない欠陌部分および異物加 らの放電出化甞防ぐことが可能と思われるのて，長期 信頼性を高方重要な意味があると考える。

最徭に，乙の研究を道じ激励とご指導をいだ゙いた 木村研究所長，ならびにご指導，ご討諭をいただいた 研究所ならびに関係各位に厚く祘礼雨し上げる。

(昭和 48 年 9 月 3 日受付, 同 49 年 4 月 18 日再受利)

\section{文献}

(1) F. H. Kreuger: CIGRE No. 21-02 (1968)

(2) 池田・高橋: 電気学会諭文誌 92-A，120(昭 47-3)

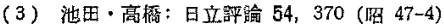

(4) T. Kojima, et al.: IEEE Trans. Paper, T 73-501-4 (1973)

(5) 不破, 他：昭47電受学会全大 No. 331

（6）長畸，倠：住友電気 No. 106, 1 (昭 47-5)

（7）高㭼，他：招48電気学会全大 No. 1134

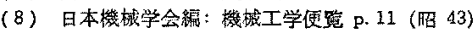

（9）たとえば，高柳諭文策：Report Research Using "Vibron" Model DDV-II Vol. 31 (1966)

(10) J.L. Matheus, et al.: Acta. cryst 2, No. 85, (1949)

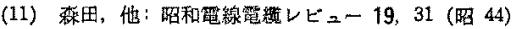

(12) R. A. Fave: J. Polymer Sci. Part-D Macromolecular Re. views 5, (1971)

(13) P. R. Fitchmun, et al. : J. Polymer Sci. Part A-2, 8, 1545 (1970)

(14) B. Yoda \& K , Muraki: IEEE Trans. Power Apparatus Syst. PAS-92, 506 (1973)

(15) H. Yamauchi, et al. : IEEE Trans. Paper, C-72-504-9 (1972)

(16) 周田，他：眧48要気学会全大 No.246

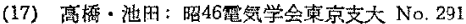

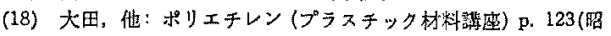
36) 日刊工紫

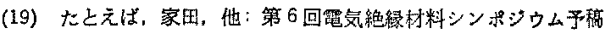
集 (鬥 48-9)

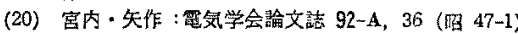

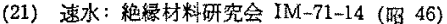

(22) 石原・矢作：昭44電氛四学全速夫 No. 266

(23) 会田，他：瞳48雪気学会全大 No. 278

(24) 岩田，他：同上 No.248 